\title{
Relationship between folate status and tumour progression in patients with hepatocellular carcinoma
}

\author{
Chang-Sheng Kuo ${ }^{1,2}$, Ching-Yih $\mathrm{Lin}^{3}$, Meng-Ying $\mathrm{Wu}^{1}$, Chin-Li Lu ${ }^{4}$ and Rwei-Fen Huang ${ }^{1}$ * \\ ${ }^{1}$ Department of Nutritional Science, Fu Jen University, Hsin-Chuang 242, Taiwan \\ ${ }^{2}$ Department of Nutrition, ${ }^{3}$ Section of Gastroenterology and Hepatology, Department of Internal Medicine \\ and ${ }^{4}$ Department of Medical Research, Chi-Mei Medical Center, Tainan, Taiwan
}

(Received 4 June 2007 - Revised 4 December 2007 - Accepted 10 December 2007 - First published online 14 February 2008)

Previous studies with folate/methyl-deficient rat models proposed the role of folate deficiency in hepatocarcinogenesis and tumour progression. We investigated the relationship between folate status and tumour progression in patients with hepatocellular carcinoma (HCC). Ninety HCC patients (age 62 (SD 10) years) recruited through the Department of Internal Medicine, Chi-Mei Hospital, participated in this cross-sectional study. According to the clinical criteria, $44 \%$ showed marginal folate deficiency (serum folate $7-14 \mathrm{nmol} / \mathrm{l}$; folate intake 278 (SD 212 ) $\mu \mathrm{g} / \mathrm{d}$ ), and $16 \%$ were folate deficient $(<7 \mathrm{nmol} / 1 ; 207$ (SD 113) $\mu \mathrm{g} / \mathrm{d}$ ). Serum folate showed inverse correlations with three elements of tumour progression: tumour size $(r-0.29 ; P=0.005)$, tumour multiplicity $(r-0.24 ; P=0.018)$ and metastasis $(r-0.39 ; P=0.0001)$. When HCC progression was categorised into stages I to IV, serum folate decreased as HCC stage progressed (stage I, 24.5 (SD 11.5); stage IV, 10.3 (SD 3.3) nmol/l; $P=0.032$ ). After adjustment for age, sex, lifestyle and dietary factors, patients with low blood folate status (serum folate $<14 \mathrm{nmol} / 1$ ) had increased risks for advanced tumour progression in large tumours (OR $7 \cdot 1$ (95\% CI 2.27, 21.9); $P=0.0007$ ), tumour multiplicity (OR $3 \cdot 2$ (95\% CI 1.07, 3.51); $P=0.004)$ and metastasis (OR 4.5 (95\% CI 1.11, 18.4); $P=0.03$ ) relative to those with normal folate status. Further controlling for liver injury, tumour proliferation and tumour stage, however, negated the effect of folate on advanced tumour progression. The data thus suggest that low blood folate status could be a risk factor for tumour progression, which is modulated by clinical lesions present in HCC patients. Future studies with larger sample sizes are warranted to explore the joint effects of low folate and hepatic lesions in human HCC malignancy.

Folate status: Hepatocellular carcinoma: Tumour progression

Hepatocellular carcinoma (HCC) is the third most frequent cause of death due to malignancies in men, and its incidence is increasing worldwide ${ }^{(1-3)}$. High incidences, easy metastasis and frequent recurrence even after ablation mean that patients with advanced HCC have little chance of survival. Infection with hepatitis $\mathrm{B}$ and $\mathrm{C}$ viruses and ingestion of aflatoxin $\mathrm{B}_{1}$-contaminated food remain the major risk factors for HCC in $\mathrm{Asia}^{(4)}$. Age, sex and alcohol-related cirrhosis are associated with HCC development ${ }^{(4,5)}$. Relatively little is known about the nutritional status of HCC patients and its relationship with HCC development. A recent prospective cohort study showed an association of low blood folate levels with risks for liver damage and $\mathrm{HCC}^{(6)}$, suggesting a possible role of folate in the carcinogenesis of human HCC.

Folate plays a central role in one-carbon metabolism in the liver. An adequate folate status supplies the liver with available one-carbon carriers for de novo thymidylate and purine synthesis, amino acid interconversion and methylation of macromolecules ${ }^{(7)}$. Chronic liver diseases such as viral hepatitis ${ }^{(8,9)}$, alcoholic liver disorder ${ }^{(10)}$ and liver cirrhosis ${ }^{(11-13)}$ may compromise the folate status, as low blood folate levels are commonly found in patients with those diseases. In animal studies, folate deficiency leads to genomic instability, including increased DNA strand breaks ${ }^{(14)}$, hypomethylation within the p53 tumour suppressor gene (14-16) $^{(14)}$ and altered expression of genes involved in cell-cycle regulation $^{(17)}$, all of which have been proposed as plausible mechanisms that link folate deficiency to liver tumour progression $^{(18)}$. Disturbance of one-carbon metabolism by a methyl-deficient diet (deficient in folate, choline and methionine) has been shown to promote tumour progression in rat liver ${ }^{(19,20)}$. The folate status of HCC patients in relation to tumour progression, however, has not been assessed.

Accordingly, the aims of the present study were to investigate the folate status of HCC patients and its relationship to tumour progression. Ninety HCC patients recruited through the Department of Internal Medicine, Chi-Mei Hospital, participated in this cross-sectional study. We studied serum 
folate levels, dietary folate intake, general nutritional status and clinical data, including liver damage and tumour progress.

\section{Materials and methods}

\section{Subjects}

Between April 2005 and October 2006, 120 potentially eligible patients with $\mathrm{HCC}$ were recruited through the Department of Internal Medicine of Chi-Mei Hospital (Tainan, Taiwan). Chi-Mei Hospital provides medical services to a defined population base in southern Taiwan. Patients were diagnosed with HCC by imaging examinations, including B-type ultrasonography, computed tomography, MRI and angiography. The diagnosis of HCC progression (size, number and metastasis) was made by two physicians specialised in hepatology and oncology. For patients with a tumour size of $1-2 \mathrm{~cm}$, the presence of HCC was histologically confirmed. All studied patients had primary HCC. Diagnosis of liver cirrhosis was also histologically proven. HCC patients with cardiac or renal diseases, overt diabetes, or active intravenous drug abuse were excluded. Patients with severe illness or who were unwilling to donate extra blood samples withdrew from the study. In total, ninety $\mathrm{HCC}$ patients participated in the entire study. Informed consent was secured from all study participants. The protocol was approved by the Committee on Medical Research of Chi-Mei Hospital and the Ethical Review Board of Fu-Jen University.

\section{Risk factors and dietary assessment}

Within 1 week following the diagnosis of HCC and before treatment in scheduled consultations, patients were asked to donate fasting blood samples and to complete questionnaires concerning their medical history, personal habits and use of medications. Demographic data, smoking status and alcohol consumption were recorded. Experienced dietitians helped patients complete a semi-quantitative FFQ covering the previous year to assess their habitual dietary folate intake. Their current folate intake was assessed by a $24 \mathrm{~h}$ recall at the time of the HCC diagnosis. The questionnaire was developed in our laboratory for assessing the folate intake of Taiwanese ${ }^{(21)}$. It has been validated by multiple $24 \mathrm{~h}$ recalls $(r 0.86$; $P<0.001)^{(21)}$ and by plasma folate levels $(r 0.57 ; P<0.001)^{(8)}$.

\section{Blood biochemical determinations}

Peripheral blood samples were taken after a $12 \mathrm{~h}$ fasting period, chilled, and transported to the laboratory, where serum samples were immediately separated upon arrival. The time between blood sampling and separation of serum for total homocysteine (tHcy) determinations was restricted to $2 \mathrm{~h}$. thcy levels were measured by fluorescence polarisation immunoassay (Becton Dickinson, Orangeburg, NY, USA). Serum folate was determined with a commercial RIA kit (Becton Dickinson). Serum glutamic-oxaloacetic transaminase (GOT), alanine aminotransferase (ALT) and albumin concentrations were measured by standard techniques (ITC Diagnostics, Taiwan). Hb was measured in a Coulter STKS counter (Beckman Coulter, Miami, FL, USA).

\section{Classification of tumour progression}

HCC progression was classified according to recognised criteria by the tumour, regional lymph node, and metastases (TNM) system $^{(22)}$. The classification considers the presence or absence of vascular invasion, the number of tumour nodules (single $v$. multiple) and the size of the largest tumour $(<5 v$. $\geq 5 \mathrm{~cm}$ ). In brief, primary tumour progression was categorised as T1 (solitary tumour without vascular invasion), T2 (solitary tumour with vascular invasion or multiple tumours none more than $5 \mathrm{~cm}$ ), T3 (multiple tumours more than $5 \mathrm{~cm}$ or a tumour involving a major branch of the portal or hepatic veins) or T4 (with metastasis). Tumour stage grouping was defined as stages I-III for T1, T2 and T3, respectively, with no regional lymph node metastasis or distant metastasis. Stage IV was defined as any primary tumour with metastasis in any regional lymph node or distant metastasis.

\section{Statistical analysis}

Data are presented as mean values and standard deviations. According to the clinical criteria, serum folate status of individuals was classified as normal (serum folate $>14 \mathrm{nmol} / \mathrm{l}$ or $6 \mathrm{ng} / \mathrm{ml})$, marginally deficient $(7-14 \mathrm{nmol} / \mathrm{l}$ or $3-6 \mathrm{ng} / \mathrm{ml})$ or deficient $(<7 \mathrm{nmol} / 1 \text { or } 3 \mathrm{ng} / \mathrm{ml})^{(23,24)}$. As serum folate levels of patients were stratified into various folate statuses, the absolute frequencies of categorical variables such as sex, viral infection and the presence of clinical complications were compared using the $\chi^{2}$ test. Demographic and laboratory data of continuous variables were compared using one-way ANOVA followed by Duncan's multiple range test. Dependence between the folate status and tumour progression markers was evaluated using Pearson's correlation coefficient. Logistic regression models were used to estimate the OR and $95 \%$ CI for large tumours $(\geq 5 \mathrm{~cm})$, tumour multiplicity $(\geq 2)$, and metastasis with respect to normal folate status (serum folate $\geq 14 \mathrm{nmol} / \mathrm{l}$ ) $v$. deficient folate status (serum folate $<14 \mathrm{nmol} / \mathrm{l}$ ). Non-normally distributed dependent variables were first log-transformed. Statistical analyses were performed using the Statistical Analysis System (SAS/STAT version 6.12; SAS Institute, Cary, NC, USA). Differences were considered to be statistically significant at $P<0.05$.

\section{Results}

Baseline and clinical characteristics of the studied hepatocellular carcinoma patients

Table 1 presents the baseline and clinical data of the HCC patients. Of the ninety patients, $80 \%$ had a first-time diagnosis of $\mathrm{HCC}$ and $20 \%$ had recurrent $\mathrm{HCC}$ within an interval of 6-24 months following their first surgical resection or transarterial chemoembolisation. A total of $44 \%$ of patients were seropositive for hepatitis B surface antigen, $46 \%$ were positive for serum anti-hepatitis $\mathrm{C}$ virus antibody, and the remaining $10 \%$ were non- $\mathrm{B}$, non-C. The mean age of patients was 62 (SD 10) years. No obvious disorders with cholesterol metabolism or kidney dysfunction were observed. Seventy-three percent had liver cirrhosis. Clinical complications included ascites $(37 \%)$, portal vein thrombosis $(20 \%)$ and hepatic encephalopathy $(12 \%)$. 
Table 1. Baseline and clinical data of ninety patients with hepatocellular carcinoma

(Mean values and standard deviations)

\begin{tabular}{|c|c|c|c|}
\hline Variables & Mean & & SD \\
\hline \multicolumn{4}{|l|}{ Cases $(n)$} \\
\hline New cases & & 72 & \\
\hline Recurrent cases & & 18 & \\
\hline \multicolumn{4}{|l|}{ Virological types $(n)$} \\
\hline Hepatitis $B$ virus & & 40 & \\
\hline Hepatitis C virus & & 41 & \\
\hline \multicolumn{4}{|l|}{$\operatorname{Sex}(n)$} \\
\hline Male & & 65 & \\
\hline Female & & 25 & \\
\hline Age (years) & 62 & & 10 \\
\hline BMI $\left(\mathrm{kg} / \mathrm{m}^{2}\right)$ & 24 & & $3 \cdot 2$ \\
\hline Albumin $(g / l)$ & $34 \cdot 7$ & & $6 \cdot 6$ \\
\hline Cholesterol $(\mu \mathrm{g} / \mathrm{l})$ & $161 \cdot 3$ & & $48 \cdot 1$ \\
\hline Creatinine $(\mu \mathrm{g} / \mathrm{l})$ & 1.09 & & 0.49 \\
\hline \multicolumn{4}{|c|}{ Glutamic-oxaloacetic transaminase (U/I) } \\
\hline Median & & $90 \cdot 5$ & \\
\hline Range & & $23-793$ & \\
\hline \multicolumn{4}{|c|}{ Alanine aminotransferase (U/I) } \\
\hline Median & & 67 & \\
\hline Range & & $15-446$ & \\
\hline \multicolumn{4}{|l|}{ Cirrhosis } \\
\hline$n$ & & 66 & \\
\hline$\%$ & & 73 & \\
\hline \multicolumn{4}{|l|}{ Ascites } \\
\hline$n$ & & 33 & \\
\hline$\%$ & & 37 & \\
\hline \multicolumn{4}{|c|}{ Portal vein thrombosis } \\
\hline$n$ & & 18 & \\
\hline$\%$ & & 20 & \\
\hline \multicolumn{4}{|c|}{ Hepatic encephalopathy } \\
\hline$n$ & & 11 & \\
\hline$\%$ & & 12 & \\
\hline
\end{tabular}

Demographic, lifestyle and nutritional variables by serum folate status

According to the clinical criteria, $44 \%$ of HCC patients showed marginal folate deficiency (serum folate $7-14 \mathrm{nmol} / \mathrm{l}$ ) and $16 \%$ were folate deficient $(<7 \mathrm{nmol} / \mathrm{l})$ (Table 2$)$. Patients with deficient serum folate had a significantly lower habitual folate intake (207 (SD 113) v. 336 (SD 190) $\mu \mathrm{g} / \mathrm{d}$; $P=0.032$ ), higher serum tHcy concentrations (14.1 (SD 6.2) $v$. 9.6 (SD 4.8) $\mu \mathrm{mol} / 1 ; P=0.001$ ) and higher frequencies of alcohol intake (36 v. 14\%; $P=0.019$ ) than those with normal serum folate levels. Serum folate levels were not significantly different by age, BMI, smoking habit, albumin level or Hb level.

Hepatic damage, clinical complications and tumour markers in hepatocellular carcinoma patients with various folate statuses

As shown in Table 3, neither liver injury (GOT and ALT levels) nor clinical complications (cirrhosis and ascites) were correlated with serum folate levels. Patients with folate deficiency had significantly higher $\alpha$-fetal protein levels (1137 (SD 3838) v. 8 (SD 28) $\mu \mathrm{g} / \mathrm{l} ; P=0.037$ ), larger tumours (10 (SD 14.3) v. 3.0 (SD 2.7) $\mathrm{cm} ; P=0.0003$ ), more tumours (3 (SD 0.6) v. 2.2 (SD 1.0); $P=0.042$ ) and higher metastasis rate $(64 v .11 \% ; P=0.0002)$ than those with normal folate levels $(\geq 14 \mathrm{nmol} / \mathrm{l})$. Values of the clinical parameters in patients with marginal folate deficiency lay between those of the folate-deficient and normal-folate groups. Pearson's correlation coefficient revealed inverse correlations between serum folate and tumour size $(r-0.29 ; P=0.005)$, tumour multiplicity $(r-0.24 ; P=0.018)$ and metastasis rate $(r-0.391$; $P=0.0001)$.

\section{Folate status and clinical factors in relation to hepatocellular carcinoma stages}

When HCC progression was categorised into stages I to IV ${ }^{(22)}$, tumour progression was associated with lower serum folate levels (stage I 24.5 (SD 11.5) v. stage IV 10.3 (SD 3.3) nmol/l; $P=0.032$ ), independent of folate intake (Table 4). Advanced tumour staging was associated with elevated $\alpha$-fetal protein levels $(P=0 \cdot 001)$ and lower BMI $(P=0.032)$. No significant differences in general nutritional status (albumin and Hb levels) and liver injury (GOT and ALT levels) between tumour stages were observed.

Odds ratios of hepatocellular carcinoma progression by blood folate status

We used a blood folate level of less than $14 \mathrm{nmol} / \mathrm{l}$ (the cut-off point for marginal and deficient folate levels) to represent low blood folate status for further analysis (Table 5). The OR of advanced tumour progression associated with low blood folate levels relative to normal serum folate status $(\geq 14 \mathrm{nmol} / \mathrm{l}$ ) was $7 \cdot 1$ for large tumours (95\% CI 2.27, 21.9; $P=0.007$ ), 3.2 for multiple tumours (95\% CI 1.07, 3.51; $P=0.04)$ and $4.5(95 \%$ CI $1.11,18.4 ; P=0.03)$ for metastasis after controlling for age, sex, lifestyle and dietary factors (model A; Table 5). Further controlling for liver injury, tumour proliferation and tumour stages, however, negated the effect of folate on advanced tumour progression (models $\mathrm{B}$ and $\mathrm{C})$.

\section{Discussion}

According to the clinical criteria ${ }^{(23,24)}, 44 \%$ of HCC patients showed marginal folate deficiency, and $16 \%$ were folate deficient. Elevated tHcy concentrations in these patients confirmed a functional folate insufficiency ${ }^{(25)}$. The causes of low blood folate status in HCC patients are unknown. Several factors may contribute. Malnourishment is commonly found in some cancer patients ${ }^{(26)}$, and may compromise the serum folate status. Impaired liver function is reported to accompany a low folate status and high tHcy levels, especially in patients with viral hepatitis ${ }^{(8,9)}$, alcoholic liver disorder ${ }^{(10)}$ and liver cirrhosis $^{(11-13)}$. In the present study, the low serum folate levels were not associated with changes in BMI, levels of albumin, Hb, GOT or ALT, or liver cirrhosis (Tables 2 and 3). It is likely that low folate status was associated with general ill-health of HCC patients, yet was not detected due to low numbers of the study or a low predictive value of the nutritional marker. A recent study reported that folate and $\mathrm{B}$ vitamin status of HCC patients were reduced as HCC progressed $^{(27)}$. Our data confirmed that serum folate decreased as HCC stage progressed (Table 4). The findings raise the possibility that low folate status could be an intrinsic 
Table 2. Demographic, lifestyle and nutritional variables by serum folate status of patients with hepatocellular carcinoma (HCC) $\dagger$ (Mean values and standard deviations)

\begin{tabular}{|c|c|c|c|c|c|c|c|}
\hline \multirow[b]{3}{*}{ Variables } & \multicolumn{7}{|c|}{ Serum folate levels $\ddagger$} \\
\hline & \multicolumn{2}{|c|}{$\begin{array}{l}\text { Deficiency } \\
(<7 \mathrm{nmol} / \mathrm{l})\end{array}$} & \multicolumn{2}{|c|}{$\begin{array}{l}\text { Marginal deficiency } \\
\quad(7-14 \mathrm{nmol} / \mathrm{l})\end{array}$} & \multicolumn{3}{|c|}{$\begin{array}{c}\text { Normal } \\
(>14 \mathrm{nmol} / /)\end{array}$} \\
\hline & Mean & SD & Mean & SD & Mean & & SD \\
\hline \multicolumn{8}{|l|}{ Number of patients } \\
\hline$n$ & \multicolumn{2}{|c|}{14} & \multicolumn{2}{|c|}{40} & \multicolumn{3}{|c|}{36} \\
\hline$\%$ & \multicolumn{2}{|c|}{16} & \multicolumn{2}{|c|}{44} & \multicolumn{3}{|c|}{40} \\
\hline Age (years) & $61 \cdot 1$ & 11.3 & $63 \cdot 3$ & 9.4 & $61 \cdot 0$ & & $12 \cdot 1$ \\
\hline \multicolumn{8}{|l|}{ Sex } \\
\hline Male & \multirow{2}{*}{\multicolumn{2}{|c|}{$\begin{aligned} & 13^{*} \\
& 1^{*}\end{aligned}$}} & \multirow{2}{*}{\multicolumn{2}{|c|}{32}} & \multicolumn{3}{|c|}{20} \\
\hline Female & & $1^{*}$ & & 8 & \multicolumn{3}{|c|}{16} \\
\hline BMI $\left(\mathrm{kg} / \mathrm{m}^{2}\right)$ & 22.5 & $2 \cdot 7$ & 24.4 & 3.5 & $24 \cdot 2$ & & $2 \cdot 9$ \\
\hline \multicolumn{8}{|l|}{ Regular alcohol intake§ } \\
\hline$n$ & \multicolumn{2}{|c|}{5} & \multicolumn{2}{|c|}{15} & \multicolumn{3}{|c|}{5} \\
\hline$\%$ & \multicolumn{2}{|c|}{$36^{*}$} & \multicolumn{2}{|c|}{28} & \multicolumn{3}{|c|}{14} \\
\hline \multicolumn{8}{|l|}{ Smoking habit\| } \\
\hline$n$ & \multirow{2}{*}{\multicolumn{2}{|c|}{$\begin{array}{r}8 \\
57\end{array}$}} & \multirow{2}{*}{\multicolumn{2}{|c|}{$\begin{array}{l}25 \\
62\end{array}$}} & \multirow{2}{*}{\multicolumn{3}{|c|}{$\begin{array}{l}14 \\
38\end{array}$}} \\
\hline$\%$ & & & & & & & \\
\hline \multirow{2}{*}{$\begin{array}{l}\text { Current folate intake }(\mu \mathrm{g} / \mathrm{d}) \text { q } \\
\% \text { of DRI }\end{array}$} & \multirow[t]{2}{*}{134} & 98 & \multirow[t]{2}{*}{196} & 163 & 189 & & 102 \\
\hline & & & & & & 47 & \\
\hline Habitual folate intake $(\mu \mathrm{g} / \mathrm{d}) \dagger \dagger$ & $207^{*}$ & 113 & 278 & 212 & 336 & & 190 \\
\hline$\%$ of DRI & & & & & & 76 & \\
\hline Serum tHcy levels $(\mu \mathrm{mol} / \mathrm{l})$ & $14 \cdot 1^{*}$ & $6 \cdot 2$ & $12 \cdot 5$ & $5 \cdot 3$ & $9 \cdot 6$ & & 4.8 \\
\hline Albumin levels $(\mathrm{g} / \mathrm{l})$ & $36 \cdot 6$ & 8.4 & 38.4 & 6.9 & 33.8 & & 5.4 \\
\hline $\mathrm{Hb}(\mathrm{g} / \mathrm{l})$ & $12 \cdot 4$ & $2 \cdot 3$ & $12 \cdot 2$ & 2.5 & 12.5 & & $2 \cdot 2$ \\
\hline
\end{tabular}

DRI, dietary reference intake.

* Value was significantly different from that of the normal-folate group $(P<0.05)$.

† Data of continuous variables were compared using one-way ANOVA followed by Duncan's multiple range test. The $\chi^{2}$ test was used for categorical variables.

¥ Serum folate status of individuals was classified into normal $(\geq 14 \mathrm{nmol} / \mathrm{l})$, marginal deficiency $(7-14 \mathrm{nmol} / \mathrm{l})$ or deficiency $(<7 \mathrm{nmol} / \mathrm{l})$ according to the clinical criteria $(23,24)$

$\S$ Regular alcohol intake was defined as one or more drinks per week.

\| Smoking habit was defined as never smoking, or not smoking in the 6 months before the diagnosis of HCC.

ๆ Current dietary intake was assessed by $24 \mathrm{~h}$ recall. DRI of elderly healthy individuals for folate is $400 \mu \mathrm{g} / \mathrm{d}$.

†† Habitual folate intake was the dietary intake in the last year, as assessed by a semi-quantitative frequency questionnaire.

consequence of tumour growth. There may be an increased demand for folate as tumours grow. Alternatively, we found that the low serum folate in HCC patients was associated with a low habitual folate intake, suggesting the possible contribution of chronic insufficient dietary folate intake to their low folate status. Whether variations in eating habits and dietary patterns or germline methylenetetrahydrofolate reductase C677T genotype (a marker of long-term folate status) affect the blood folate status of HCC patients is under our investigation.

One of our major findings is that low blood folate status could be a risk factor for tumour progression. After adjustment for age, sex, lifestyle and dietary factors, we found increased risks for tumour progression in large tumours (OR 7.1; $95 \%$ CI $2 \cdot 27,21.9$ ), tumour multiplicity (OR $3.2 ; 95 \%$ CI 1.07 , 3.51 ) and metastasis (OR 4.5; $95 \%$ CI 1.11, 18.4) in HCC patients with deficient blood folate levels. The finding is consistent with results from the folate/methyl-deficient rat model of hepatocarcinogenesis showing that a methyl-deficient diet promoted tumour progression in rat liver ${ }^{(18-20)}$. Chronic dietary folate/methyl deficiency is known to result in genomic DNA strand breakage ${ }^{(14)}$, uracil misincorporation, hypomethylation within the p53 tumour suppressor gene (14-16) $^{\text {and }}$ altered expression of genes involved in cell-cycle regulation $^{(17)}$, all of which contribute to in vivo carcinogenesis ${ }^{(18)}$ and possibly to multiple tumour development. Genomewide hypomethylation and decreased expression of tumour suppressor genes ( $p 53$ and $p 16^{I N K 4 A}$ ) were observed in early pre-neoplastic liver tumours in rats fed a folate/methyldeficient diet ${ }^{(28,29)}$ and in patients with $\mathrm{HCC}^{(30,31)}$, and may deregulate apoptotic and proliferation processes ${ }^{(32)}$ to favour the development of large tumours. Our data together with results of folate-deficient animal studies support the hypothesis that HCC progression may be associated with low blood folate status. However, the possibility of reverse causality cannot be excluded in the present study given the fact that serum folate decreased as HCC stage progressed, independent of dietary folate intake (Table 4). Whether the mechanistic relationships exist between deficient folate levels, large tumours and tumour multiplicity in human HCC, as proposed in rodent models of hepatocarcinogenesis, will depend on future research results.

It is notable that adjustment for liver injury (ALT levels), tumour proliferation ( $\alpha$-fetal protein levels) and tumour staging, however, negated the effect of folate on the increased risk of advanced tumour progression. The data suggest that clinical lesions present in HCC patients are important confounders that modulate the effect of low folate status in advanced HCC progression. Although the mechanisms that promote human HCC malignancy remain unclear, cancer metastasis is thought to involve complex multi-steps including growth, angiogenesis, dissemination, invasion and survival of cancer cells ${ }^{(33,34)}$. In response to the in vivo microenvironment, differential changes of the primary tumours including 
Table 3. Hepatic injuries, clinical complications and tumour progression by serum folate status of patients with hepatocellular carcinomał (Mean values and standard deviations)

\begin{tabular}{|c|c|c|c|c|c|c|}
\hline \multirow[b]{3}{*}{ Variables } & \multicolumn{6}{|c|}{ Serum folate levels§ } \\
\hline & \multicolumn{2}{|c|}{$\begin{array}{l}\text { Deficiency } \\
(<7 \mathrm{nmol} / \mathrm{l})\end{array}$} & \multicolumn{2}{|c|}{$\begin{array}{l}\text { Marginal deficiency } \\
\quad(7-14 \mathrm{nmol} / \mathrm{l})\end{array}$} & \multicolumn{2}{|c|}{$\begin{array}{c}\text { Normal } \\
(>14 \mathrm{nmol} / \mathrm{l})\end{array}$} \\
\hline & Mean & SD & Mean & SD & Mean & SD \\
\hline Glutamic-oxaloacetic transaminase (U/l) & 162 & 143 & 133 & 140 & 101 & 60 \\
\hline Alanine aminotransferase $(\mathrm{U} / \mathrm{l})$ & 93 & 119 & 94 & 81 & 100 & 67 \\
\hline \multicolumn{7}{|l|}{ Cirrhosis } \\
\hline$n$ & \multicolumn{2}{|c|}{9} & \multicolumn{2}{|c|}{31} & \multicolumn{2}{|c|}{26} \\
\hline$\%$ & \multicolumn{2}{|c|}{64} & \multicolumn{2}{|c|}{78} & \multicolumn{2}{|c|}{72} \\
\hline \multicolumn{7}{|l|}{ Ascites } \\
\hline$n$ & \multicolumn{2}{|c|}{7} & \multicolumn{2}{|c|}{15} & \multicolumn{2}{|c|}{8} \\
\hline$\%$ & \multicolumn{2}{|c|}{50} & \multicolumn{2}{|c|}{38} & \multicolumn{2}{|c|}{22} \\
\hline \multicolumn{7}{|l|}{ Portal vein thrombosis } \\
\hline$n$ & \multirow{2}{*}{\multicolumn{2}{|c|}{$\begin{array}{c}5 \\
36 \dagger\end{array}$}} & \multirow{2}{*}{\multicolumn{2}{|c|}{$\begin{array}{c}8 \\
20\end{array}$}} & \multirow{2}{*}{\multicolumn{2}{|c|}{$\begin{array}{c}8 \\
22\end{array}$}} \\
\hline$\%$ & & & & & & \\
\hline$\alpha$-Fetal protein $(\mu \mathrm{g} / \mathrm{l})$ & $1137^{\star}$ & 3838 & 125 & 420 & 8 & 28 \\
\hline Tumour size $(\mathrm{cm})$ & $10 \cdot 0^{*}$ & $14 \cdot 3$ & $5 \cdot 8$ & 3.4 & 3.9 & $2 \cdot 7$ \\
\hline Tumour number $(n)$ & $3.0^{*}$ & 0.6 & 2.4 & 0.8 & $2 \cdot 2$ & $1 \cdot 0$ \\
\hline Metastasis & & & & & & \\
\hline$n$ & \multicolumn{2}{|c|}{9} & \multicolumn{2}{|c|}{7} & \multicolumn{2}{|c|}{4} \\
\hline$\%$ & \multicolumn{2}{|c|}{$64^{*}$} & \multicolumn{2}{|c|}{18} & \multicolumn{2}{|c|}{11} \\
\hline
\end{tabular}

* Value was significantly different from that of the normal-folate group $(P<0.05)$.

† Value was significantly different from that of the marginal folate-deficient group $(P<0.05)$

‡ Data of continuous variables were compared using one-way ANOVA followed by Duncan's multiple range test. The $\chi^{2}$ test was used for categorical variables.

$\S$ Serum folate status of individuals was classified into normal $(\geq 14 \mathrm{nmol} / /)$, marginal deficiency $(7-14 \mathrm{nmol} / /)$ or deficiency $(<7 \mathrm{nmol} / /)$.

a mixture of tumour cells, stromal cells and endothelial cells may play a role in tumour progression to metastasis ${ }^{(35)}$. It has been proposed that the degree of viral hepatitismediated liver damage may affect intrahepatic metastasis ${ }^{(36)}$. Thus, changes of the in vivo clinical microenvironment in HCC appear to work together and override the effects of folate deficiency on advanced HCC progression. Future studies with larger sample sizes are warranted to confirm this result and to further elucidate the combined effects of low blood folate level, liver injury and tumour behaviour in the cascade of events driving HCC malignancy.
Our findings should be interpreted in the context of a few limitations. The most important one is the relatively small sample size, which reduces the statistical power for subgroup analysis. Insufficient statistical power in multivariate analysis may provide only pilot results. The second is the possibility of error associated with dietary assessments using a $24 \mathrm{~h}$ recall or FFQ. Participants may misreport their daily intake or underestimate portion sizes, particularly when ill. Finally, the inherent limitations associated with retrospective study designs cannot conclude folate insufficiency as a cause of advanced HCC progression.

Table 4. Folate status and clinical factors in relation to hepatocellular carcinoma (HCC) stages $†$

(Mean values and standard deviations)

\begin{tabular}{|c|c|c|c|c|c|c|c|c|}
\hline \multirow[b]{3}{*}{ Variables } & \multicolumn{8}{|c|}{ HCC stagesł } \\
\hline & \multicolumn{2}{|c|}{ Stage I (n 23) } & \multicolumn{2}{|c|}{ Stage II (n 29) } & \multicolumn{2}{|c|}{ Stage III ( $n$ 18) } & \multicolumn{2}{|c|}{ Stage IV (n 20) } \\
\hline & Mean & SD & Mean & SD & Mean & SD & Mean & SD \\
\hline BMI $\left(\mathrm{kg} / \mathrm{m}^{2}\right)$ & 24.4 & $2 \cdot 2$ & $24 \cdot 2$ & $2 \cdot 1$ & 24.6 & 1.5 & $22 \cdot 2^{*}$ & 2.5 \\
\hline Current folate intake $(\mu \mathrm{g} / \mathrm{d}) \S$ & 211 & 110 & 177 & 151 & 188 & 199 & 161 & 109 \\
\hline Habitual folate intake $(\mu \mathrm{g} / \mathrm{d}) \|$ & 278 & 127 & 328 & 200 & 330 & 295 & 213 & 110 \\
\hline Serum folate levels $(\mathrm{nmol} / \mathrm{l})$ & 24.5 & 11.5 & $17 \cdot 3$ & 5.7 & 13.4 & 2.3 & $10 \cdot 3^{*}$ & $3 \cdot 3$ \\
\hline Albumin levels $(\mathrm{g} / \mathrm{l})$ & $37 \cdot 3$ & 0.6 & 32.5 & 0.6 & 33.8 & 0.5 & $35 \cdot 3$ & 0.8 \\
\hline $\mathrm{Hb}$ levels $(\mathrm{g} / \mathrm{l})$ & $12 \cdot 3$ & $2 \cdot 8$ & 12.5 & 1.9 & $12 \cdot 7$ & 2.4 & 11.7 & $2 \cdot 3$ \\
\hline Glutamic-oxaloacetic transaminase levels (U/I) & 108 & 154 & 131 & 94.6 & 113 & 85.6 & 145 & 121 \\
\hline Alanine aminotransferase levels (U/l) & 83.7 & 59.5 & $122 \cdot 2$ & 93.9 & 77.4 & 59.9 & $90 \cdot 4$ & 98.8 \\
\hline$\alpha$-Fetal protein levels $(\mu \mathrm{g} / \mathrm{l}) \boldsymbol{q}$ & 1.6 & 1.0 & 1.7 & 0.9 & $2 \cdot 4$ & 1.7 & $3 \cdot 1^{*}$ & 1.8 \\
\hline
\end{tabular}

* Mean value was significantly different from that of the stage I group $(P<0.05)$.

† Statistical difference was determined by one-way ANOVA followed by Duncan's multiple range test.

$\ddagger$ HCC staging was classified according to recognised criteria of the tumour, regional lymph node, and metastases (TNM) system. Detailed descriptions are given in Materials and methods.

$\S$ Current dietary intake was assessed by $24 \mathrm{~h}$ recall.

|| Habitual folate intake was the dietary intake in the last year, as assessed by a semi-quantitative frequency questionnaire.

I Data of $\alpha$-fetal protein levels were log-transformed. 
Table 5. Risk of hepatocellular carcinoma (HCC) progression by blood folate level

(Odds ratios and $95 \%$ confidence intervals)

\begin{tabular}{|c|c|c|c|c|c|c|c|c|}
\hline \multirow{2}{*}{ Serum folate levels } & \multirow{2}{*}{\multicolumn{2}{|c|}{ Tumour progression }} & \multicolumn{6}{|c|}{ HCC progression† } \\
\hline & & & \multicolumn{2}{|c|}{ Model Ał } & \multicolumn{2}{|c|}{ Model B§ } & \multicolumn{2}{|c|}{ Model C\| } \\
\hline Folate $\geq 14 \mathrm{nmol} / \mathrm{I}$ & 8 & 29 & \multicolumn{2}{|c|}{1.0} & \multicolumn{2}{|c|}{1.0} & \multicolumn{2}{|r|}{$1 \cdot 0$} \\
\hline$<14 \mathrm{nmol} / \mathrm{l}$ & 34 & 19 & $7 \cdot 1$ & $2 \cdot 2,21 \cdot 9$ & $5 \cdot 9$ & $1 \cdot 8,19 \cdot 3$ & $3 \cdot 1$ & $0.91,10.7$ \\
\hline Multiple tumours & $\geq 2$ & 1 & & & & & \multirow{2}{*}{\multicolumn{2}{|c|}{1.0}} \\
\hline Folate $\geq 14 \mathrm{nmol} / \mathrm{l}$ & 23 & 14 & \multicolumn{2}{|c|}{1.0} & \multicolumn{2}{|c|}{1.0} & & \\
\hline$<14 \mathrm{nmol} / \mathrm{l}$ & 44 & 9 & $3 \cdot 2$ & $1.07,3.51$ & 3.9 & $1 \cdot 1,13 \cdot 6$ & $2 \cdot 6$ & $0.68,9.79$ \\
\hline$P$ & & & \multirow{2}{*}{\multicolumn{2}{|c|}{$0.004^{*}$}} & \multicolumn{2}{|c|}{$0.03^{*}$} & \multicolumn{2}{|r|}{0.16} \\
\hline Metastasis & Yes & No & & & & & & \\
\hline Folate $\geq 14 \mathrm{nmol} / \mathrm{l}$ & 4 & 33 & \multicolumn{2}{|c|}{$1 \cdot 0$} & \multicolumn{2}{|c|}{$1 \cdot 0$} & \multicolumn{2}{|r|}{1.0} \\
\hline$<14 \mathrm{nmol} / \mathrm{l}$ & 16 & 37 & 4.5 & $1 \cdot 1,18 \cdot 4$ & $4 \cdot 6$ & $0.75,29 \cdot 1$ & 1.9 & $0.24,14.6$ \\
\hline$P$ & & & & & & & & 0.54 \\
\hline
\end{tabular}

* Statistically significant at $P<0.05$.

$\dagger$ Advanced tumour progression is defined as tumour size $\geq 5 \mathrm{~cm}$, tumour number $\geq 2$ and metastasis development.

Model A: adjusted for age, sex, alcohol intake and habitual folate intake.

$\S$ Model B: adjusted for all parameters in model A with the addition of albumin, alanine aminotransferase levels and portal vein thrombosis.

|| Model C: adjusted for all parameters in model B with the addition of $\alpha$-fetal protein levels and tumour stages.

Despite these limitations, our data provide several implications for HCC prognosis. For clinical treatment of advanced HCC, hepatic resection followed by intrahepatic arterial chemotherapy using the antifolate drug 5-fluorouracil may place more metabolic pressure on the unidentified folate deficiency of HCC patients ${ }^{(37,38)}$. Persistent folate deficiency during the clinical course of HCC could aggravate nutrition problems if left untreated. Further longitudinally designed and interventional studies with a large sample size may help determine the optimal strategies to improve low folate status of HCC patients and to explore the possible interactions with combined clinical conditions for better prognosis.

\section{Acknowledgements}

The authors gratefully acknowledge the assistance of Ms Wan Shen Lin in sample collection and lymphocyte extraction. The study was supported by grants from the Department of Health, Taiwan (DOH95-TD-F-113-008 to R.-F. S. H.). There are no financial or other contractual agreements that might cause conflicts of interest. C.-S. K. and C.-Y. L. contributed equally to the study.

\section{References}

1. El-Serag HB \& Mason AC (1999) Rising incidence of hepatocellular carcinoma in the United States. $N$ Engl J Med 340, 745-750.

2. Parkin DM, Bray F, Ferlay J \& Pisani P (2001) Estimating the world cancer burden: Globocan 2000. Int J Cancer 94, $153-156$.

3. Taylor-Robinson SD, Foster GR, Arora S, Hargreaves S \& Thomas HC (1997) Increase in primary liver cancer in the UK, 1979-94. Lancet 350, 1142-1143.

4. Chen CJ, Yu MW \& Liaw YF (1997) Epidemiological characteristics and risk factors of hepatocellular carcinoma. J Gastroenterol Hepatol 12, S294-S308.
5. Koike Y, Shiratori Y, Sato S, et al. (2000) Risk factors for recurring hepatocellular carcinoma differ according to infected hepatitis virus - an analysis of 236 consecutive patients with a single lesion. Hepatology 32, 1216-1223.

6. Welzel TM, Katki HA, Sakoda LC, Evans AA, London WT, Chen G, O'Broin S, Shen FM, Lin WY \& McGlynn KA (2007) Blood folate levels and risk of liver damage and hepatocellular carcinoma in a prospective high-risk cohort. Cancer Epidemiol Biomarkers Prev 16, 1279-1282.

7. Shane B (1995) Folate chemistry and metabolism. In Folate in Health and Disease, pp. 1-22 [LB Bayley, editor]. New York: Marcel Dekker.

8. Kao CS (2003) Relationships between vitamin status, plasma homocysteine and hepatitis in Taiwanese population. MS Thesis, Department of Nutritional Science, Fu-Jen University, Hsin-Chuang, Taiwan.

9. Tkaczewski W, Niedzielska H, Malafiej E, Dworniak D \& Dramiski M (1971) Studies of serum folic acid level in patients with viral hepatitis. Pol Med J 10, 1081-1084.

10. Wu A, Chanarin I, Slavin G \& Levy AJ (1975) Folate deficiency in the alcoholic - its relationship to clinical and haematological abnormalities, liver disease and folate stores. Br J Haematol 29 , 469-478.

11. Bosy-Westphal A, Petersen S, Hinrichsen H, Czech NJ \& Muller M (2001) Increased plasma homocysteine in liver cirrhosis. Hepatol Res 20, 28-38.

12. Ferre N, Gomez F, Camps J, Camps J, Simo JM, Murphy MM, Fernandez-Ballart J \& Joven J (2002) Plasma homocysteine concentrations in patients with liver cirrhosis. Clin Chem 48, $183-185$.

13. García-Tevijano ER, Berasain C, Rodríguez JA, Corrales FJ, Arias R, Martin-Duce A, Caballeria J, Mato JM \& Avila MA (2001) Hyperhomocysteinemia in liver cirrhosis: mechanisms and role in vascular and hepatic fibrosis. Hypertension 38, 1217-1221.

14. Pogribny IP, Basnakian AG, Miller BJ, Lopatina NG, Poirier LA \& James SJ (1995) Breaks in genomic DNA and within the $p 53$ gene are associated with hypomethylation in livers of folate/methyl-deficient rats. Cancer Res 55, 1894-1901.

15. Kim YI, Pogribny IP, Basnakian AG, Miller JW, Selhub J, James SJ \& Mason JB (1997) Folate deficiency in rats induces 
DNA strand breaks and hypomethylation within the $p 53$ tumor suppressor gene. Am J Clin Nutr 65, 46-52.

16. Pogribny IP, Miller BJ \& James SJ (1997) Alterations in hepatic p53 gene methylation patterns during tumor progression with folate/methyl deficiency in the rat. Cancer Lett 115, 31-38.

17. Crott JW, Choi SW, Ordovas MJ, Ditelberg JS \& Mason JB (2004) Effects of dietary folate and aging on gene expression in the colonic mucosa of rats: implications for carcinogenesis. Carcinogenesis 25, 69-76.

18. James SJ, Pogribny IP, Pogribna M, Miller BJ, Hernigan S \& Melnyk S (2003) Mechanisms of DNA damage, DNA hypomethylation, and tumor progression in the folate/methyldeficient rat model of hepatocarcinogenesis. J Nutr 133, 3740S-3747S.

19. Ghoshal AK \& Farber E (1984) The induction of liver cancer by a dietary deficiency of choline and methionine without added carcinogens. Cancer Res 5, 1367-1370.

20. Mikol YB, Hoover KL, Creasia D \& Poiner LA (1983) Hepatocarcinogenesis in rats fed methyl-deficient, amino acid-defined diets. Carcinogenesis 4, 1619-1629.

21. Lee CH, Lee FY, Wong J, Tzeng MS \& Huang RFS (2003) Design of food frequency questionnaire for assessing dietary folate: its application to study consumption frequency of folate-rich foods in ischemic stroke patients. Nutr Sci J 28, 210-217.

22. Greene FL, Balch CM, Page DL, Haller DG, Fleming ID, Morrow M \& Fritz AG (2002) TNM classification of malignant tumors. In Cancer Staging Handbook, 6th ed., pp. 142-154 [FL Greene, editor]. New York: Berlin Heidelberg.

23. Waters AH, Mollin DL, Pope J \& Towler T (1961) Studies on the folic acid activity of human serum. J Clin Pathol 14, $335-351$.

24. Herbert V (1986) The 1986 Herman Award Lecture. Nutrition science as a continually unfolding story: the folate and vitamin B-12 paradigm. Am J Clin Nutr 46, 387-402.

25. Selhub J, Jacques PF, Wilson PWF, Rush D \& Rosenberg IH (1993) Vitamin status and intake as primary determinants of homocysteinemia in an elderly population. JAMA $\mathbf{2 7 0}$, 2693-2698.

26. Shimizu Y, Nagaya N, Isobe T, Imazu M, Okumura H, Hosoda H, Kojima M, Kangawa K \& Kohno N (2003) Increased plasma ghrelin level in lung cancer cachexia. Clin Cancer Res 9, 774-778.
27. Lin C-C \& Yin M-C (2007) B vitamins deficiency and decreased anti-oxidative state in patients with liver cancer. Eur J Nutr 46, 293-299.

28. Pogribny IP \& James SJ (2002) De novo methylation of the $p 16^{I N K 4 A}$ gene in early preneoplastic liver and tumors induced by folate/methyl deficiency in rats. Cancer Lett 187, 69-75.

29. Pogribny IP, James SJ, Jernigan S \& Pogribna M (2004) Genomic hypomethylation is specific for preneoplastic liver in folate/ methyl deficient rats and does not occur in non-target tissues. Mutat Res 548, 53-59.

30. Zhang YJ, Ahsan H, Chen Y, Lunn RM, Wang LY, Chen SY, Lee PH, Chen CJ \& Santella RM (2002) High frequency of promoter hypermethylation of RASSF1A and p16 and its relationship to aflatoxin B1-DNA adduct levels in human hepatocellular carcinoma. Mol Carcinogenesis 35, 85-92.

31. Zhang YJ, Chen Y, Ahsan H, Lunn RM, Lee PH, Chen CJ \& Santella RM (2003) Inactivation of the DNA repair gene $\mathrm{O}^{6}$-methylguanine-DNA methyltransferase by promoter hypermethylation and its relationship to aflatoxin B1-DNA adducts and $p 53$ mutation in hepatocellular carcinoma. Int $\mathrm{J}$ Cancer 103, 440-444.

32. James SJ, Miller BJ, Basnakian AG, Pogribny IP, Pogribna M \& Muskhelishvili L (1997) Apoptosis and proliferation under conditions of deoxynucleotide pool imbalance in liver of folate/ methyl deficient rats. Carcinogenesis 18, 287-293.

33. Hanahan D \& Weinberg RA (2000) The hallmarks of cancer. Cell 100, 57-70.

34. Budhu BS, Zipser B, Forgues M, Ye Q-H, Sun Z \& Wang XW (2005) The molecular signature of metastases of human hepatocellular carcinoma. Oncology 69, 23-27.

35. Steeg PS (2005) New insights into the tumor metastatic process revealed by gene expression profiling. Am J Pathol 166, 1291-1295.

36. Budhu BS, Zipser B, Forgues M, Ye Q-H, Sun Z \& Wang XW (2005) The molecular signature of metastases of human hepatocellular carcinoma. Oncology 69, 23-27.

37. Damdinsuren B, Nagano H \& Monden M (2007) Combined intra-arterial 5-fluorouracil and subcutaneous interferon- $\alpha$ therapy for highly advanced hepatocellular carcinoma. Hepatol Res 37, S238-S250.

38. Robien K (2005) Folate during antifolate chemotherapy: what we know and do not know. Nutr Clin Pract 20, 411-422. 